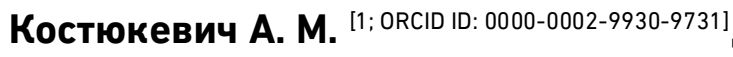
к.е.н., доцент,

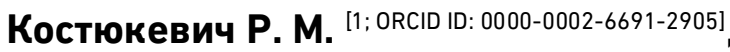
к.е.н., доцент,

Антонюк С. Ю. ${ }^{[1 ;}$ ORCID ID: 0000-0001-7407-0130] здобувач вищої освіти першого (бакалаврського) рівня

${ }^{1}$ Національний університет водного господарства та природокористування, м. Рівне

\title{
РОЗВИТОК МОЛОДІЖНОї ПОЛІТИКИ В СІЛЬСЬКИХ ГРОМАДАХ
}

у статті досліджено розвиток молодіжної політики у сільських громадах Рівненської області. Проаналізовано наявність стратегічних документів на офіційних сайтах сільських ОТГ Рівненської області. Виявлено, що тільки $18 \%$ ОТГ мають програми розвитку молоді. На основі опитування встановлено, що в багатьох громадах відсутні заходи для розвитку молоді та не враховується думка молоді у соціальноекономічному розвитку громади.

Ключові слова: молодь; молодіжна політика; сільські громади; об'єднані територіальні громади (ОТГ); програми розвитку молоді.

Укладення Україною Угоди про асоціацію з Європейським Союзом стало важливим фактором, який запустив реформи у сфері державного управління та місцевого самоврядування. Децентралізація влади і ресурсів дала поштовх до розвитку територіальних громад. Одним із напрямків діяльності місцевих органів влади є створення умов для соціального становлення та розвитку молоді в об'єднаних територіальних громадах.

Проте впродовж останніх років простежується тенденція, коли молодь масово залишає сільські громади. Попри великі сподівання на децентралізацію, яка мала б створити умови для соціальнокультурного розвитку, суттєвих змін не відбулося.

Аналіз останніх досліджень. Про необхідність розвитку соціальної сфери в умовах децентралізації та участі у цьому процесі молоді написано багато наукових праць. Значні наукові доробки у даній сфері належать Є. Бородіну, Н. Бровко, Н. Мішиній, В. Мотречко, Т.Тарасенко та ін. Зокрема науковці зазначають, що в умовах децентралізації зростає роль виконавчих комітетів ОТГ у визначенні напрямів та забезпеченні реалізації молодіжної політики, а також, що ефективність молодіжної політики залежить від єдності та скоординованості дій виконавчої влади, місцевого самоврядування і 
самої молоді [1; 2; 3; 4]. Вагомий внесок у дослідження реалізації молодіжної політики в Україні зробили М.Перепелиця, М. Головенько, Г.Коваль [5], однак, незважаючи на вагомість зазначених напрацювань, недостатньо вирішеними залишаються проблеми розвитку молодіжної політики саме у сільських громадах.

Постановка завдання. Сьогодні в Україні проживає понад 11,2 мільйонів молодих людей, що становить 27\% населення держави. Але у пошуках роботи та кращого життя велика кількість молодих й кваліфікованих спеціалістів часто виїжджають з сільських громад. Саме тому важливо, щоб місцеві громади, визначали систему стимулів, які б допомогли зупинити міграцію молодих людей із сіл. Адже соціально-економічний розвиток територіальних громад значною мірою залежить від розвитку людського капіталу. Тому дослідження розвитку молодіжної політики у сільських громадах як фактору розвитку людського капіталу $€$ важливою науковопрактичною проблемою.

Виклад основного матеріалу. Децентралізація влади призвела до значних системних змін в нашій країні. Передача нових повноважень та фінансових ресурсів на місця дозволили підвищити спроможність територіальних громад та створили передумови для їх сталого розвитку. Проте у багатьох сільських територіальних громадах простежуються і негативні процеси, що проявляються в економічній деградації, у негативних демографічних тенденціях та низькому рівні якості соціальних послуг.

Основою соціально-економічного розвитку громади $\epsilon$ програмно-цільове управління. Згідно з нормами закону України «Про добровільне об'єднання територіальних громад», держава здійснює фінансову підтримку добровільного об'єднання територіальних громад сіл, селищ, міст і приєднання до об'єднаних територіальних громад шляхом надання об'єднаній територіальній громаді коштів у вигляді субвенцій на формування відповідної інфраструктури згідно з планом соціально-економічного розвитку такої територіальної громади [6, ст. 10]. Це означає, що основним документом, що має визначати питання стратегічного розвитку територіальної громади, є план (програма) соціально-економічного розвитку.

Згідно 3 «Моделлю реалізації молодіжної політики на рівні міської/селищної/сільської ОТГ», затвердженою Міністерством молоді та спорту України, на регіональному рівні діють структурні підрозділи з питань молоді обласних державних адміністрацій, які розробляють регіональні програми розвитку та підтримки молоді 3 
урахуванням рекомендацій профільного міністерства та територіальних особливостей, а на місцевому рівні - це структурні підрозділи, які відповідають за молодіжну політику, розробляють та впроваджують міські (сільські, селищні) програми по реалізації молодіжної політики на території з огляду на особливості міста (району) або ОТГ [7]. Тобто основним документом, який регулює молодіжну політику в громадах, є програми з їх реалізації.

Однак, як показують результати аналізу наявності таких документів на сайтах сільських ОТГ Рівненської області, більшість територіальних громад не мають затверджених стратегій розвитку, програм соціально-економічного розвитку, програм розвитку молоді.

Із загальної кількості ОТГ Рівненської області тільки 20\% мають стратегії розвитку і лише у $18 \%$ стратегій наявні стратегічні та операційні цілі, які стосуються молодіжної політики (рис. 1).

ОТГ,стратегії, яких містять стратегічні та операціїні цілі, які стосуються молодіжної політики

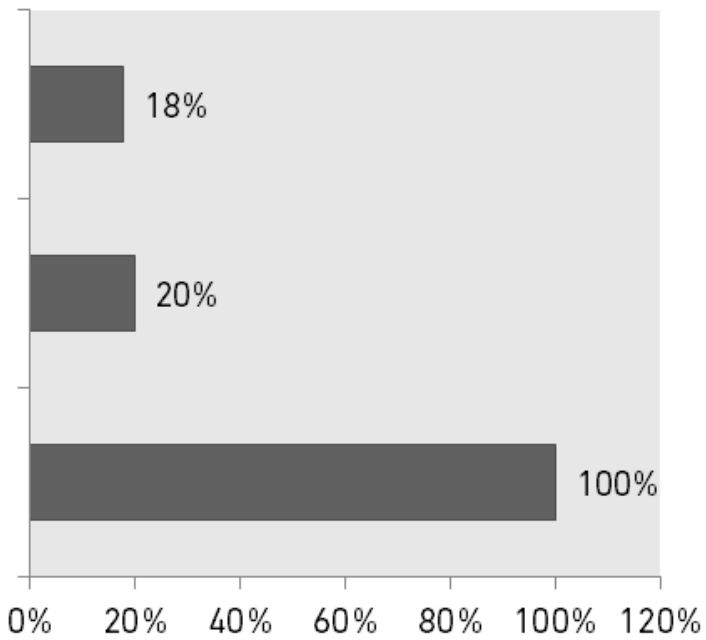

Рис. 1. Наявність стратегій розвитку на офіційних сайтах сільських ОТГ

Трохи краща ситуація 3 розробленням i затвердженням програм соціально-економічного розвитку сільських територіальних громад. Такі програми наявні у 63\% ОТГ із загальної кількості, в яких тільки 18\% мають розділ, що стосується розвитку молоді (Корнинська ОТГ, Олександріївська ОТГ, Старосільська ОТГ та Тараканівська ОТГ).

Програми розвитку молоді мають лише $18 \%$ сільських ОТГ Рівненської області, з яких фінансуються за рахунок коштів сільського бюджету програми у Немовицькій ОТГ, Тараканівській ОТГ, Миляцькій ОТГ та Ярославицькій ОТГ.

Як свідчать результати аналізу, на території сільських громад Рівненської області $€$ лише 4 молодіжні центри (Бугаївська ОТГ, 
Кричильська ОТГ, Малинська ОТГ, Шпанівська ОТГ) та 12 зареєстрованих молодіжних громадських організацій.

Наведені дані свідчать про низький рівень розвитку молодіжної інфраструктури, що негативно позначається на створенні сприятливого середовища в громадах для неформального розвитку молодих громадян, зокрема організації дозвілля, спілкування, платформ для комунікацій, обмінних молодіжних програм.

Для кращого розуміння розвитку молодіжної політики нами було проведено анкетування молодих осіб віком від 18 до 21 року, які проживають у сільських громадах. Вибіркова сукупність сформована випадковим способом відбору, щоб відбір респондентів з генеральної сукупності здійснювався у випадковому порядку. Це дало можливість дотримання принципу однакової можливості для потрапляння у вибіркову сукупність для усіх одиниць генеральної сукупності. Чисельність вибірки становить 92 особи.

На думку опитаних молодих осіб, в їхніх громадах майже відсутні заходи для розвитку молоді. Більшість респондентів вважає, що для цього не вистачає неформальної освіти, спортивних заходів, культурно-мистецьких заходів, розважальних заходів (рис. 2).

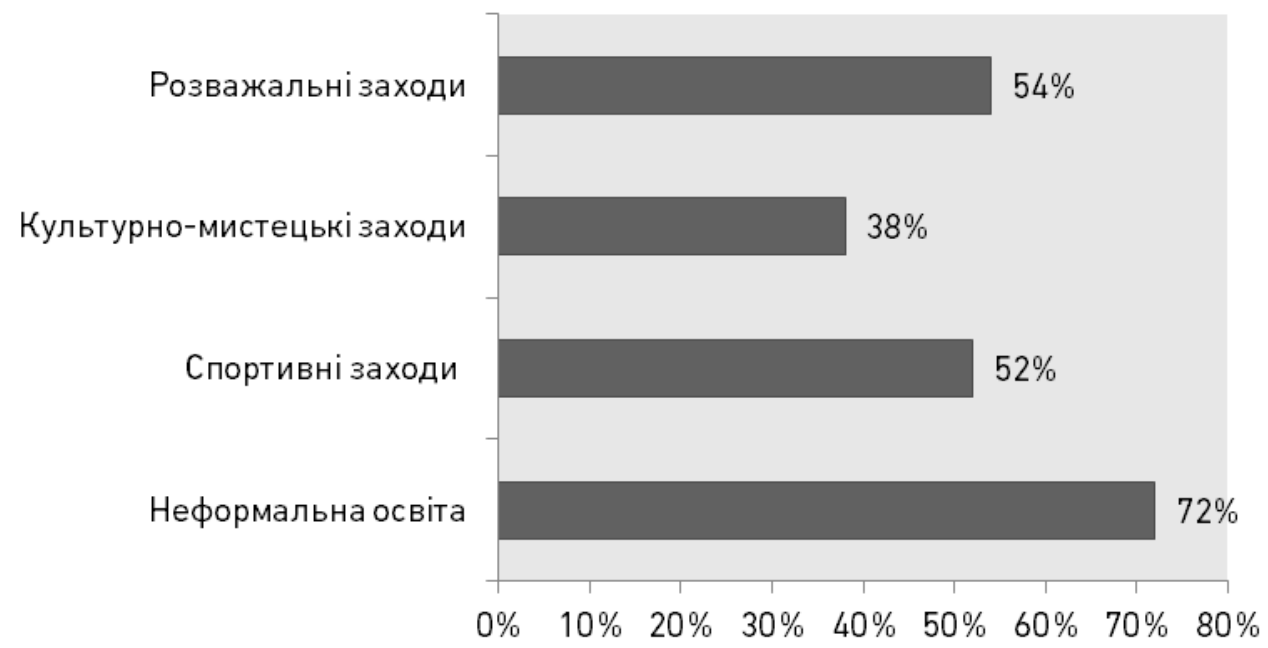

Рис. 2. Потреба у заходах, необхідних для розвитку молоді у сільських громадах

Головними напрямками розвитку молодіжної політики молоді люди визначили розвиток молодіжної інфраструктури, популяризацію здорового способу життя, організацію спортивних заходів, підтримку талановитої молоді, зайнятість молоді у сільських громадах (рис. 3). 


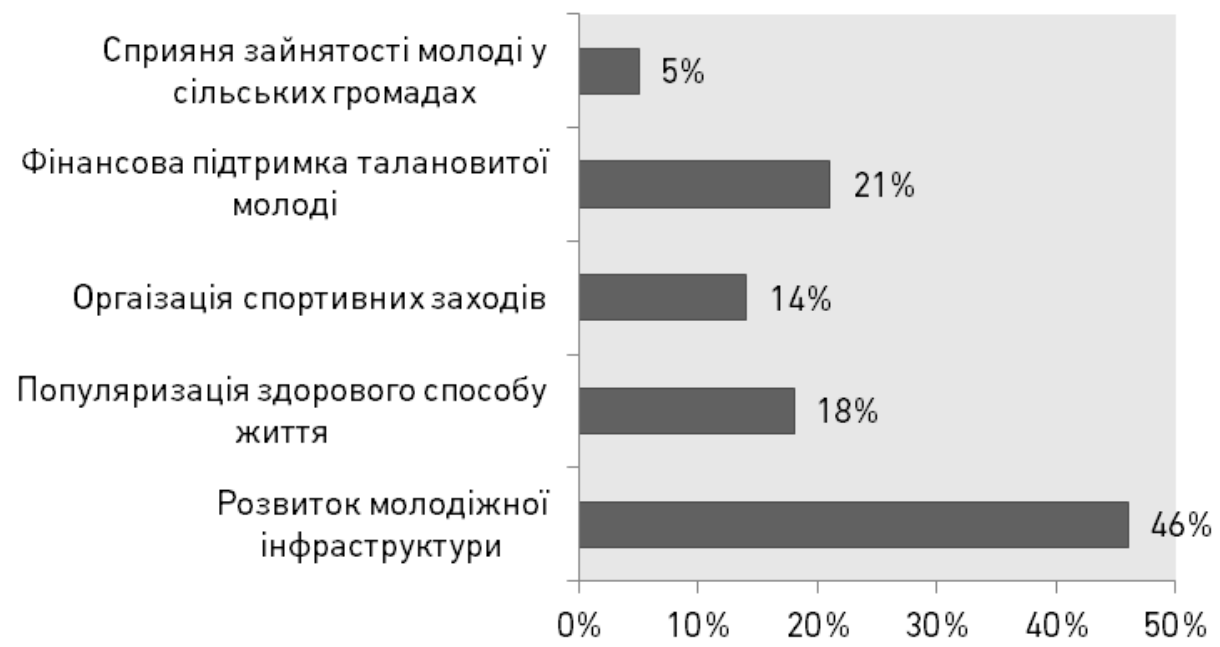

Рис. 3. Пріоритетні напрямки розвитку молодіжної політики

Розвиток ефективної молодіжної політики в умовах децентралізації можливий лише за умови об'єднання зусиль i координації діяльності органів виконавчої влади, органів місцевого самоврядування та молоді. Але, на думку опитаної молоді, місцева влада не завжди враховує їхню думку при ухваленні рішень, пов'язаних з розвитком ОТГ. Із загальної кількості респондентів лише $8 \%$ стверджують, що молодь бере участь у соціальноекономічному розвитку громади (рис. 4).

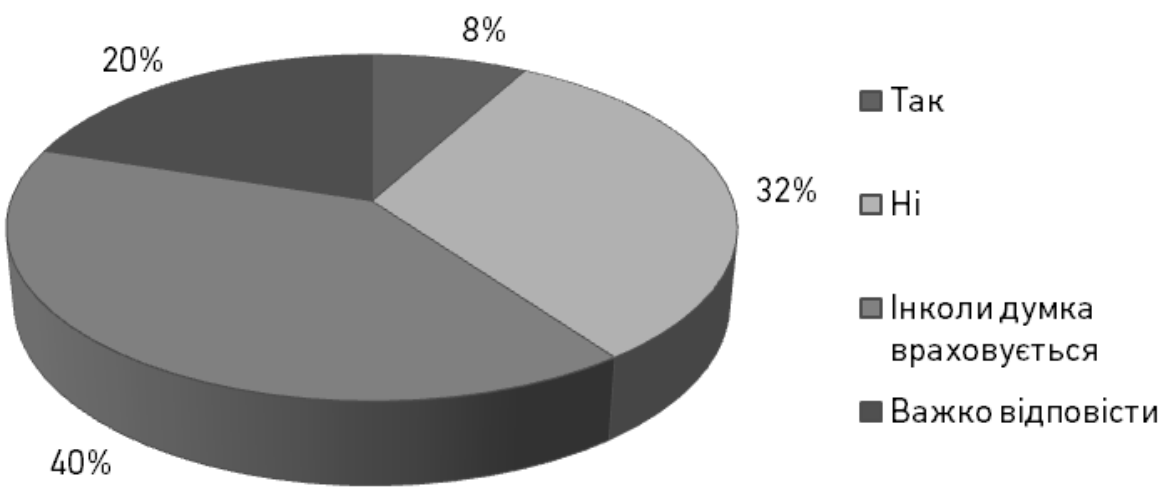

Рис. 4. Участь молоді у соціально-економічному розвитку ОТГ

Проведений аналіз показує, що сільським територіальним громадам потрібно шукати інноваційні шляхи розвитку молодіжної політики, що стане запорукою зміцнення людського капіталу та створення передумов сталого розвитку. У цьому контексті доцільно скористатися досвідом країн Європейського Союзу, де одним із 
вагомих факторів реалізації молодіжної політики $є$ створення молодіжних центрів.

Перенесення кращих європейських практик діяльності молодіжних центрів на українські сільські територіальні громади створить можливості для динамічного розвитку молодіжної політики.

Попри те, що нормативно-правова база, яка регулює діяльність молодіжних центрів, в Україні лише починає формуватися [8], територіальні громади можуть напрацьовувати власні механізми їх підтримки за допомогою цільових молодіжних програм, спрямованих на підтримку конкретних молодіжних рухів та ініціатив. Як показує практика, в багатьох громадах такі механізми працюють, про що свідчать непоодинокі історії успіху у багатьох регіонах України [9].

Розвиваючи молодіжні центри у сільських територіальних громадах як основну інституцію у системі молодіжної політики, на державному рівні можна використати досвід Європейського керівного комітету у справах молоді щодо видання знаків якості для молодіжних центрів, адаптувавши його у певну модель добровільної сертифікації таких центрів, що може бути пов'язане їх подальшою ресурсною підтримкою.

Висновки. Пріоритетним напрямком розвитку молодіжної політики у сільських громадах $€$ залучення молоді до участі у розробленні програм розвитку молоді. Адже залучення молоді до реєстрації громадських організацій, створення молодіжних центрів, дорадчих органів при місцевих радах дозволить молодим людям відчути себе повноцінним учасниками демократичних процесів та стати більш відповідальними за власні рішення. Вважаємо, що використання кращих європейських практик молодіжної політики та досвіду українських молодіжних організацій створить синергетичний ефект, який прискорить створення належних інституційних та економічних умов для самореалізації молоді у сільських територіальних громадах.

1. Бородін Є.І., Хожило І.І., Тарасенко Т. М. Управління соціально-гуманітарною сферою в процесі добровільного об'єднання територіальних громад: теоретичний та практичний аспекти. Аспекти публічного управління. 2015. № 5-6. С. 65-75. 2. Мішина Н.В. Про перспективи залучення молоді до участі у місцевому самоврядуванні в Україні. Наук. пр. Нац. ун-ту «Одеська юридична академія» : зб. наук. пр. НУ ОЮА. 2013. Т. 13. С. 304-309. 3. Мотречко В. Вплив органів місцевого самоврядування на розвиток молодіжної політики в Україні. Актуальні проблеми державного управління. 2015. Вип. 2. С. 151-155. 4. КовальГ. В. Розвиток державної молодіжної політики: теорія, методологія, механізми реалізації. Миколаїв : Вид-во ЧдУ ім. Петра Могили, 2013. С. 119. 5. Бровко Н. І. Формування та реалізація молодіжної політики в сільській місцевості в умовах децентралізації. Порівняльно-аналітичне право. 2017. № 6. С. 60-62. 6. Про добровільне об'єднання територіальних громад: Закон України від 05.02.2015 р. № 157-VIII. URL: 
Серія «Економічні науки»

Випуск 4(92) 2020 p.

https://zakon.rada.gov.ua/laws/show/157-19 (дата звернення: 10.12.2020). 7. Про модель реалізації молодіжної політики на рівні міської/селищної/сільської ОТГ : рішення колегії Міністерства молоді та спорту України від 27.12.2017 р. № 71/3/17. URL: http://dsmsu.gov.ua/index/ua/material/35078 (дата звернення: 12.12.2020). 8. Про основні засади молодіжної політики. Проєкт закону України. URL: https://w1.c1.rada.gov.ua/pls/zweb2/webproc4_1?pf3511=69244 (дата звернення: 12.12.2020). 9. URL: http://mission.youthplatform.com.ua/wpcontent/uploads/2020/01/www.youth-worker.org_.ua-2019.pdf (дата звернення: 12.12.2020).

\section{REFERENCES:}

1. Borodin Ye. I., Khozhylo I. I., Tarasenko T. M. Upravlinnia sotsialno-humanitarnoiu sferoiu $v$ protsesi dobrovilnoho obiednannia terytorialnykh hromad: teoretychnyi ta praktychnyi aspekty. Aspekty publichnoho upravlinnia. 2015. № 5-6. S. 65-75. 2. Mishyna N. V. Pro perspektyvy zaluchennia molodi do uchasti u mistsevomu samovriaduvanni v Ukraini. Nauk. pr. Nats. un-tu «Odeska yurydychna akademiia» : zb. nauk. pr. NU OluA. 2013. T. 13. S. 304-309. 3. Motrechko V. Vplyv orhaniv mistsevoho samovriaduvannia na rozvytok molodizhnoi polityky $\vee$ Ukraini. Aktualni problemy derzhavnoho upravlinnia. 2015. Vyp. 2. S. 151-155. 4. Koval H. V. Rozvytok derzhavnoi molodizhnoi polityky: teoriia, metodolohiia, mekhanizmy realizatsii. Mykolaiv : Vyd-vo ChDU im. Petra Mohyly, 2013. S. 119. 5. Brovko N. I. Formuvannia ta realizatsiia molodizhnoi polityky $v$ silskii mistsevosti $v$ umovakh detsentralizatsii. Porivnialnoanalitychne pravo. 2017. № 6. S. 60-62. 6. Pro dobrovilne obiednannia terytorialnykh hromad : Zakon Ukrainy vid 05.02.2015 r. № 157-VIII. URL: https://zakon.rada.gov.ua/laws/show/157-19 (data zvernennia: 10.12.2020). 7. Pro model realizatsii molodizhnoi polityky na rivni miskoi/selyshchnoi/silskoi OTH : rishennia kolehii Ministerstva molodi ta sportu Ukrainy vid 27.12.2017 r. № 7-1/3/17. URL: http://dsmsu.gov.ua/index/ua/material/35078 (data zvernennia: 12.12.2020). 8. Pro osnovni zasady molodizhnoi polityky. Proiekt zakonu Ukrainy. URL: https://w1.c1.rada.gov.ua/pls/zweb2/webproc4_1?pf3511=69244 (data zvernennia: 12.12.2020). 9. URL: http://mission.youthplatform.com.ua/wpcontent/uploads/2020/01/www.youth-worker.org_.ua-2019.pdf (data zvernennia: 12.12.2020).

Kostiukevych A. M. [1; ORCID ID: 0000-0002-9930-9731], Candidate of Economics (Ph.D.), Associate Professor,

Kostiukevych R. M. [1; ORCID ID: 0000-0002-6691-2905], Candidate of Economics (Ph.D.), Associate Professor, Antoniuk S. Y. ${ }^{[1 ;}$ ORCID ID: 0000-0001-7407-0130], Senior Student ${ }^{1}$ National University of Water and Environmental Engineering, Rivne

\section{DEVELOPMENT OF YOUTH POLICY IN RURAL COMMUNITIES}

Today, more than $\mathbf{1 1 . 2}$ million young people live in Ukraine, which is $\mathbf{2 7} \%$ of the country's population. However, in search of work and a better 
life, a large number of young and qualified professionals often leave communities. That is why it is important that local communities, at the stage of unification, identify a system of incentives that would help stop the migration of young people from small settlements.

Decentralization of power is already significantly changing our country, the transfer of new powers and financial resources to the field has increased the capacity of communities and they are becoming stronger and more successful. However, such development is not characterized by the stability of processes. As a result, some of the united territorial communities barely make ends meet, while others receive large incomes. And many communities have never decided to volunteer.

According to the results of the analysis of the availability of such documents on the websites of RTC of Rivne region, most territorial communities do not have approved development strategies, socio-economic development programs and youth development programs. Of the total number of OTGs in Rivne region, only $20 \%$ have development strategies and only $18 \%$ of strategies have strategic and operational goals related to youth policy.

The implementation of an effective youth policy in the context of decentralization is possible only if the efforts of the executive authorities, local governments and youth representation are combined. According to the results of the analysis, there are only 4 youth centers (Bugaivska RTC, Krychylska RTC, Malynska RTC, Shpanivska RTC) and 12 registered public organizations in the rural communities of Rivne region. These data indicate a low level of development of youth infrastructure, which negatively affects the creation of a favorable environment in communities for informal development of young people, including leisure, communication, communication platforms, and youth exchange programs.

To better understand the development of youth policy, we conducted a survey of young people aged 18 to 21 living in rural communities. The sample is formed by a random method of selection, so that the selection of respondents from the general population was carried out at random. This made it possible to adhere to the principle of equal opportunity to be included in the sample for all units of the general population. The sample size is 92 people.

The development of an effective youth policy in the context of decentralization is possible only if the efforts of the executive, local governments and youth are combined and coordinated. However, according to the interviewed young people, the local authorities do not always take their opinion into account when making decisions related to the development of RTC. Of the total number of respondents, only $8 \%$ say that young people participate in the socio-economic development of the community

Keywords: youth; youth policy; rural communities; united territorial communities (UTC); youth development programs. 


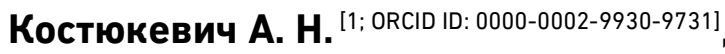
к.э.Н., доцент,

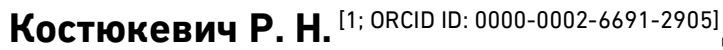
к.э.н., доцент,

Антонюк С. Ю. [1; ORCID ID: 0000-0001-7407-0130] соискатель высшего образования первого (бакалаврского) уровня

${ }^{1}$ Национальный университет водного хозяйства и природопользования, г. Ровно

\section{РАЗВИТИЕ МОЛОДЕЖНОЙ ПОЛИТИКИ В СЕЛЬСКИХ ОБЩИНАХ}

В статье исследовано развитие молодежной политики в сельских общинах Ровенской области. Проанализировано наличие стратегических документов на официальных сайтах сельских ОТО Ровенской области. Выявлено, что только $18 \%$ ОтО имеют программы развития молодежи. На основе опроса установлено, что во многих общинах отсутствуют мероприятия для развития молодежи и не учитывается мнение молодежи в социально-экономическом развитии общины.

Ключевые слова: молодежь; молодежная политика; сельские общины; объединенные территориальные общины (ОТО); программы развития молодежи. 